\title{
Organizational Learning Culture as Moderator on the Relationship Between Transformational Leadership and Affective Commitment
}

\author{
Luthfia Putri Rizkia ${ }^{\mathrm{a}, *}$, Alice Salendua ${ }^{\mathrm{a}}$ \\ ${ }^{a}$ Universitas Indonesia
}

\begin{abstract}
This study aims to investigate the effect of an organizational learning culture as a moderator on the relationship between transformational leadership and affective commitment. Framework in this study uses Social Exchange Theory to explain the moderation effect and we argue that the relationship between transformational leadership and affective commitment is strengthened by an organizational learning culture. Data were collected by administering questionnaires to the respondents using both offline and online surveys on employees from startup companies in Indonesia $(\mathrm{N}=73)$. This study using the self-report method and data were analyzed using Hayes' PROCESS macro. Results showed that organizational learning culture moderated the relationship between transformational leadership and affective commitment, such that the relationship was increased when organizational learning culture was high than when organizational learning culture was low. Moreover, theoretical and practical implications are given to the improvement of employees' affective commitment.
\end{abstract}

Keywords: affective commitment, organizational learning culture, transformational leadership

\section{INTRODUCTION}

Employees' commitment to their workplace is an important aspect that needs to be considered by managers in every organization. Employees who have a high level of commitment could increase their work performance and reduce absenteeism (Khatibi et al., 2009), meanwhile, employees who have a low level of commitment could lead to turnover intention (Islam et al., 2013).

Based on a meta-analysis, employees' commitment also leads to job satisfaction, work engagement, occupational commitment, in-role performance, citizenship behavior, and wellbeing (Meyer et al., 2002). Hence, the manager should maintain their employee commitment to keep their employees from other companies who actively looking for to recruit their rivals' employees (Islam et al., 2013).

There are three different forms of organizational commitment, namely normative, continuance, and affective commitment (Allen and Meyer, 1990). The focus of this research will be on affective commitment, it referred to employees' emotional attachment to the organization (Allen and Meyer, 1990)

\footnotetext{
*Author in correspondence,

Email address: putririzkiluthfia@gmail.com (Luthfia Putri Rizkia)
}

ISSN: 2549-3221 (Print) 2549-323X (Online)

DOI: $10.26487 /$ hebr.v5i1.2722 and considered as an essence or central characteristic of the organizational commitment that can predict absenteeism, turnover, or organizational citizenship behaviors (Mercurio, 2015). Based on previous studies, one of the factors that can influence affective commitment is transformational leadership (Meyer et al., 2002).

Previous researches showed that transformational leadership has positive and significant correlation with affective commitment $\left(\mathrm{r}=.31^{* *}, \mathrm{p}<0.01\right)(\mathrm{Kim}, 2014) ;\left(\mathrm{r}=.47^{* *}, \mathrm{p}<0.01\right)$ (Ashikali and Groeneveld, 2015); $(\mathrm{r}=.43 * *, \mathrm{p}<0.01)$ (Gulluce et al., 2016), and $\left(\mathrm{r}=.28^{* *}, \mathrm{p}<0.01\right)$ in study 1 and $\left(\mathrm{r}=.59^{* *}\right.$, $\mathrm{p}<0.01$ ) in study 2 (Triana and Richard, 2017). Meanwhile, previous research also showed that there is an insignificant relationship between transformational leadership and affective commitment ( $\mathrm{r}=.23, \mathrm{p}>0.05)$ (Ramachandran and Krishnan, 2009), thus it leads to the need for moderation variable because of the inconsistent relation in past studies between antecedent and outcome (Memon et al., 2019). Previous researches also suggest that to explain the relationship between transformational leadership and affective commitment, moderating variable is needed (Avolio et al., 2004).

This current study proposed organizational learning culture as moderating variable between transformational leadership and affective commitment. Organizational learning culture can enhance employees' commitment because it helps the company to build the condition where knowledge is created, shared, and 
used that influences employees' perceptions and behavior (Jo Joo, 2011). Previous research showed that the correlation between organizational learning culture and affective commitment is positive significantly $(\mathrm{r}=.89 * *, \mathrm{p}<0.01)$ (Khunsoonthornkit and Panjakajornsak, 2018). Organizational learning culture has also a positive and significant correlation with transformational leadership $\left(\mathrm{r}=.85^{* *}, \mathrm{p}<0.01\right)$ where this style of leadership support organizational learning culture practice at the workplace, and vice versa (Abbasi and Zamani-Miandashti (2013); (Bass et al., 2003)).

Based on previous studies, this current study will focus on investigating the effect of an organizational learning culture as a moderator on the relationship between transformational leadership and affective commitment. This study will focus on learning culture in startup company because learning culture has a close relationship and play an important role to startup company considering that this type of organization learns from their mistakes and also interpret external environment responses to the decisions made, thus learning culture can be seen clearly (Sekliuckiene et al., 2018).

\section{LITERATURE REVIEW}

\subsection{Affective Commitment}

Affective commitment can be explained as an emotional attachment that employees perceived to the organization, and also the identification with and involvement in the organization (Allen and Meyer, 1990). When employees' affective commitment is high it means they want to stay o last in the organization, and will increase their commitment when their experience in the organization in line with their expectation and satisfy to the needed that have been provided by organization (Meyer et al., 1993). Factors that become affective commitments' predictors are that personal characteristic or individual differences, and work experiences, particularly transformational leadership (Meyer et al., 2002).

\subsection{Transformational Leadership}

It can be described that transformational leadership is the type of leadership with a charismatic inspirational style that focused to align the team's goal and its members and adjusting the organizational culture (Ashikali and Groeneveld, 2015). This style of leadership is important for an organization because the leader can enhance employees' skills in creativity and innovation by empowering them psychologically (Gumusluoglu and Ilsev, 2008).

Transformational leadership can also be explained as the leaders' behavior that shows full attention to the personal growth and professionalism of their subordinates, therefore the subordinate will engage emotionally with the leader as well as their organization (Pradhan and Pradhan, 2015). Previous studies showed that transformational leadership and affective commitment have a strong correlation (Porter (2015); Pradhan and Pradhan (2015)).

\subsection{Organizational Learning Culture}

Organizational learning culture can be described as the culture that has an ability to respond or adapt to the environment in novel ways quickly while also remove the learning barriers (Marsick and Watkins, 2003). An organization that applies to learn culture in their workplace can be described as an organization that identic with its skill in creating, acquire, and transfer knowledge, and also modify its behavior when facing the new knowledge and insights (Islam et al., 2013). The organization with learning culture increase their learning capacity by making changes in strategy, structure, slack, and ideology (Meyer, 1982).

Based on the relationship between these variables, the hypothesis of this study is there is a moderation effect of organizational learning culture in the relationship between transformational leadership and affective commitment.

Using Social Exchange Theory as a framework to explain the association between transformational leadership, organizational learning culture, and affective commitment, this theory explains that there is a transaction process in the organization where individuals form positive perceptions fairly to these transactions (Cropanzano et al., 2002). Based on this theory, we can imply that when the organization behaves or supports fairly to its employees in form of a transformational leader and learning culture then the employees will form the positive perception that is shown in their high commitment to the organization. The novelty of this study along with our humble literature search is that we proposed the organizational learning culture as the variable that will explain the relationship between transformational leadership and affective commitment, while previous research use clan culture to explain it (Kim, 2014).

\section{METHOD}

\subsection{Population and Sample}

This study was conducted in startup companies in Indonesia by offline and online self-report survey methods. We sent the survey, both on paper and questionnaires' link to the companies and ask them to share the survey with all of their employees. The participant's criteria were employees who currently work in a startup company, and from the convenient sampling procedure, participants from two startup companies responded to the survey $(\mathrm{N}=73)$. We used convenience sampling to recruit participants because of availability at a given time and the participant's willingness to participate (Etikan et al., 2016). We ensured participants that their participation was voluntary and confidential and that they may stop their participation anytime they want. Participants are then asked to put their checklist on the informed consent page to participate in the survey.

\subsection{Data and Measurements}

All scales were using the Indonesian version. All scales were translated to Indonesia and validated by expert judgment. The translate-back-translate procedure was suggested by Brislin (1970). After all, scales translated to Indonesia, we conducted a pilot study before the current research began with 31 
participants using an online survey. From the pilot study, we got the results that the alpha coefficients for affective commitment are $(=0.858)$, for transformational leadership is $(=0.962)$, and for organizational learning culture is $(=0.937)$.

Affective Commitment scale was measured using 8-items (Allen and Meyer, 1990) and includes items such as "I would be very happy to spend the rest of my career with this organization". The transformational Leadership scale was measured using 12-items (Ashikali and Groeneveld, 2015). A sample item using "My leader helps employees to develop their strengths." Both scales using a Likert scale with 6-points from 1 (strongly disagree) to 6 (strongly agree).

The Organizational Learning Culture scale was measure using 14-items (Marsick and Watkins (2003); Yang et al. (2004)), the sample item is that "In my organization, people help each other learn." This scale using the Likert scale with 6-points from 1 (rarely true) to 6 (almost always true).

Data were analyzed using the Hayes' PROCESS macro. This method was to test the effect of an organizational learning culture as a moderator on the relationship between transformational leadership and affective commitment.

\subsection{Confirmatory Factor Analysis (CFA)}

We did a confirmatory factor analysis to assess the discriminant validity of our study variables by comparing two models, namely the 1-factor model (all items were reflected on one general latent variable) and the 3-factor model or hypothesis model (all items were reflected on their respective latent variables). It has been suggested that CFI and TLI values should be close to 0.9 ; RMSEA $<0.05$ means good fit, in the range $0.05-0.08$ means acceptable fit, in the range $0.08-0.10$ means marginal fit, and greater than 0.10 mens poor fit; and SRMR value is should be > 0.06 (Bentler (1990); Fabrigar et al. (1999); Hu and Bentler (1999)). After we compared the model fit indices between the 1-factor model and 3-factor model, it confirmed that the 3-factor model is well established for our research model as showed in Table 1.

Table 1: Confirmatory Factor Analysis

\begin{tabular}{llllll}
\hline Model & $\begin{array}{l}\text { Latent } \\
\text { vari- } \\
\text { ables }\end{array}$ & CFI & TLI & RMSEA & SRMR \\
\hline $\begin{array}{l}\text { Model 3- } \\
\text { factor }\end{array}$ & $\begin{array}{l}\text { TL, } \\
\text { OLC, } \\
\text { AC }\end{array}$ & 0.792 & 0.777 & 0.079 & 0.108 \\
$\begin{array}{l}\text { Model 1- } \\
\text { factor }\end{array}$ & $\begin{array}{l}\text { General } \\
\text { factor }\end{array}$ & 0.574 & 0.546 & 0.113 & 0.127 \\
\hline
\end{tabular}

Source: Author, 2019

Note: N=73, TL (Transformational Leadership), OLC (Organizational Learning Culture), AC (Affective Commitment), CFI (Comparative Fit Index), TLI (Ticker-Lewis Index), RMSEA (Root Mean Square of Approximation), and SRMR (Standardized Root Mean Square Residual)

\subsection{Checking for Common Method Bias}

We used Harman's single-factor test (Podsakoff et al., 2003) by performing an exploratory factor analysis (EFA) on all the variables to address the issue of common method bias. We found that the first factor accounted for $30.491 \%$ of the variance, indicating that common method bias may not be an issue that influences the results. We also used the latent variable approach (Podsakoff et al., 2003), by performing a confirmatory factor analysis (CFA) on all variables with $\mathrm{R}$ Studio version 3.5.1. After we compared standardized regression weights of a model with a common latent variable and the proposed model, the results showed that of the 34 items, only 1 item was beyond the threshold (0.2; Podsakoff et al. (2003)). The discriminant validity of the latent variables is established as found in the CFA result, showing that items for different constructs have no conceptual overlap. As Conway and Lance (2010) suggested, the discriminant validity test is necessary to rule out substantial method effects. Therefore, we argue that common method bias is not pervasive in this study.

\section{RESULT AND DISCUSSION}

\subsection{Description of Respondents}

For the current study, the total of participants is 73 employees with the majority of participants were male (52 employees, $71,2 \%)$. There were 35 participants (47.9\%) who were 17-25 years old, 34 participants $(46.6 \%)$ who were $26-35$ years old, and 4 participants $(5.5 \%)$ who were aged or over 36 years old, and participants' mean age was 26.62 (SD = 4.294). Concerning their length of work (job tenure), 38 participants had been employed under 1 year of work and 35 others had been employed more than 1 year. We include the data from employees whose tenure was under 1 year because the result showed that there are no significant differences between the means of transformational leadership (TL), affective commitment (AC), and organizational learning culture (OLC) across tenure group as shown in Table 2.

Table 2: Means of transformational leadership, affective commitment, and organizational learning culture

\begin{tabular}{llcc}
\hline Tenure Group & TL & AC & OLC \\
\hline 1. Less than 1 year & 4.745 & 4.45 & 4.906 \\
2. 1 year & 4.638 & 4.696 & 4.814 \\
\hline
\end{tabular}

The participants were also divided into two different rank or position, there were $52(71.2 \%)$ participants who work as staff and $21(28.8 \%)$ others work as a supervisor or team leader. The majority of the participants (60 employees, $82,2 \%$ ) have a bachelor's degree (S1) as their last educational background.

\subsection{Results of Hypothesis Test}

The result from Table 3 showed that there is a positive and significant correlation between transformational leadership and affective commitment, which implies that when transformational leadership was high, then affective commitment was also high. 
Table 3: Means, standard deviations, and correlations of variables

\begin{tabular}{lccccccccc}
\hline Variable & $M$ & SD & 1 & 2 & 3 & 4 & 5 & 6 & 7 \\
\hline 1. Age & 26.6 & 4.29 & & & & & & & \\
2. Gender & 1.29 & 0.46 & -0.208 & & & & & & \\
3. Tenure & 1.52 & 0.5 & -0.178 & 0.125 & & & & & \\
4. Rank & 1.29 & 0.46 & $.352^{* *}$ & -0.136 & $-.299^{* *}$ & & & & \\
5. Education & 2.92 & 0.62 & 0.205 & 0.085 & 0.05 & 0.184 & & & \\
6. TL & 4.69 & 0.67 & -0.037 & $-.351^{* *}$ & 0.08 & 0.099 & -0.06 & & \\
7. OLC & 4.86 & 0.57 & -0.14 & -0.055 & 0.081 & -0.101 & -103 & $.573^{* *}$ & \\
8. AC & 4.56 & 0.6 & 0.192 & -0.199 & -0.025 & $.319^{* *}$ & 0.071 & $.240^{* *}$ & 0.16 \\
\hline
\end{tabular}

Note: $\mathrm{N}=73$

According to the result in Table 3, it also showed that age ( $\mathrm{r}$ $=0.192, p>0.05)$, gender, $(r=-0.199, p>0.05)$, tenure $(r=$ $-0.25, \mathrm{p}>0.05)$, and education $(\mathrm{r}=0.159, \mathrm{p}>0.05)$ were correlated insignificantly with affective commitment, meanwhile rank was correlated significantly with affective commitment $(\mathrm{r}$ $=0.319, \mathrm{p}<0.01)$. Based on the result of correlation analysis and also previous research (Sharma Sinha, 2015; Yew, 2008), we need to consider rank as control variables.

Hypothesis testing to check moderating effect of organizational learning culture was performed using Hayes' PROCESS macro; model 1; $\mathrm{Y}=$ Affective Commitment; $\mathrm{X}=$ Transformational Leadership; and Moderator $(\mathrm{W})=$ Organizational Learning Culture. We also add variable Rank as a covariate. The following test results are presented in Table 4.

Our confidence intervals are based on a bias-corrected method with a 5,000 bootstrap sample. The hypothesis was tested using path coefficients. The hypothesis stated that organizational learning culture moderates the relationship between transformational leadership and affective commitment. Our results presented that organizational learning culture has moderating effect in the relationship between transformational leadership and affective commitment $(\mathrm{b}=.4413, \mathrm{SE}=.1212, \mathrm{p}<.001)$ as showed in Table 4. It means that organizational learning culture strengthens the positive relationship between transformational leadership and affective commitment as shown in the simple slope in Figure 1. Thus, the hypothesis was supported by the data.

Furthermore, Figure 1 showed that when individuals perceived high organizational learning culture, transformational leadership positively predicts affective commitment, as transformational leadership increases, affective commitment also increases.

The main purpose of this study that derived from employees in startup companies in Indonesia, was to test the moderating effect of organizational learning culture in the relationship between transformational leadership and affective commitment. The results of the present study generally supported that organizational learning culture moderated the relationship between transformational leadership and affective commitment, in such a way that the effect strengthen the relationship. For high organizational learning culture, transformational leadership positively predicts affective commitment, as transformational lead-

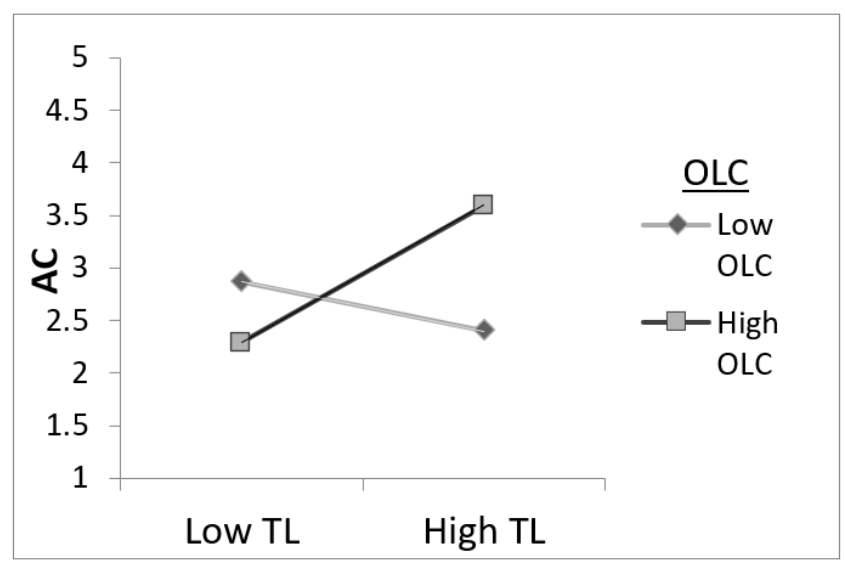

Figure 1: The simple slope of OLC as a moderator in the relationship between TL and AC

ership increases, affective commitment increases. The result implied that employee who got support both from transformational leaders and organizations who applied to learn culture in the company will increase their emotional attachment and more commitment to their workplace.

Drawing on Social Exchange Theory, organizational learning culture along with transformational leadership provided by the organization will form a positive perception in return that is showed in their high commitment to the organization (Cropanzano et al., 2002). The recent study is consistent with other studies that showed transformational leadership and affective commitment correlated significantly and positively Ashikali and Groeneveld (2015); Gulluce et al. (2016); (Kim, 2014); (Triana and Richard, 2017). Employees' commitment that showed by an eagerness to stay or attach emotionally to an organization or company enhanced by a manager who has transformational leadership qualities (Ramachandran and Krishnan, 2009), so that the employees will be committed to the organization for a long time.

Result of an organizational learning culture as a moderator in line with other studies that use a moderator to explain the relationship between transformational leadership and affective commitment, such as structural distance (Avolio et al., 2004), culture (Ramachandran and Krishnan, 2009), and status incongruence and supervisor gender (Triana and Richard, 2017). This 


\begin{tabular}{|c|c|c|c|c|c|c|}
\hline Predictor & b & $S E$ & $\mathbf{t}$ & $\mathbf{p}$ & LLCI & ULCI \\
\hline TL & 0.2095 & 0.1159 & 1.8075 & 0.0751 & -0.0218 & -0.4409 \\
\hline OLC & 0.1569 & 0.1356 & 1.1565 & 0.2515 & -0.1138 & -0.4275 \\
\hline TL $x$ OLC & 0.4413 & 0.1212 & 3.6408 & $.0005^{* *}$ & 0.1994 & 0.6832 \\
\hline Rank & 0.4067 & 0.1386 & 2.9348 & $.0045^{* *}$ & 0.1302 & 0.6832 \\
\hline $\mathrm{F}$ & \multicolumn{6}{|c|}{6.9767} \\
\hline$R^{2}$ & \multicolumn{6}{|c|}{0.291} \\
\hline$R^{2}$ change & \multicolumn{6}{|c|}{0.1382} \\
\hline
\end{tabular}

Note. N=73. TL (Transformational Leadership), OLC (Organizational Learning Culture), b(coefficient), SE (Standardized Error), LLCI (Lower Level Confidence Interval), ULCI (Upper-Level Confidence Interval). $* * \mathrm{p}<.01, * \mathrm{p}<.05$.

recent study, also implies that rank has a significant correlation with affective commitment in line with previous studies (Sharma and Sinha, 2015) as rank is higher, affective commitment increases.

From the present study, some theoretical and practical implications can be drawn. For theoretical implication, this finding adds to the theory that organizational learning culture is a culture that needed to be applied in the workplace to support the learning process especially for the organization that faced massive and rapid changing liked startup company. Employees might perceive that transformational leadership and organizational learning culture as fair treatment from their organization and in line with their need so that the employees will pay those supports with their loyalty or affective commitment to the workplace.

The understanding of the importance of organizational learning culture has also practical implications for strategies of human resources management. For practical implication, the organization should maintain their employees to enhance their commitment. First, an organization can pay attention to an employee's supervisor or manager, or team leader and make sure that the supervisor will perform to support and pay full attention to employees' growth. The organization has to make sure that subordinates feel comfortable with their supervisor's behavior. Second, an organization can create a better work environment that supports the learning process. By meanings, organization let the employees to think creatively and support innovative behavior and ideas in order to solve the problem. Organization who let employees grows their creative idea will have perceived by the employees as the comfortable workplace and their future place to spent the employees' career.

There are several limitations in this study that needed to be addressed. First, the power to generalize the finding to other start-up employees is limited. Second, the study employed a self-report survey which may lead to common method bias. Self-report is considered the most appropriate method in this study because the constructs measured in this study are highly subjective in nature, and we believe that employees are most aware of their conditions. We tried to reduce the common method bias by ensuring participants that there are no right or wrong answers and their responses are kept confidential. We also used statistical remedies to check the possibility of common method bias. However, future studies should avoid common method bias by employing different methods to collect data, such as time-lagged design. Third, the study used a cross-sectional design that limits the ability to determine the causal relationship between variables. The longitudinal design may also be employed, because transformational leadership and affective commitment may fluctuate over time.

\section{CONCLUSION}

The organization should be noted that role of the leader and organization culture or environment will increase employees' commitment. An organization who succeed to create a better learning culture and better transformational leadership will maintain and keep their employees and make their employee perform better to reach the organization's goals.

\section{References}

Abbasi, E., Zamani-Miandashti, N., 2013. The role of transformational leadership, organizational culture and organizational learning in improving the performance of iranian agricultural faculties. High Education 66, 505-519. URL: https : //doi .org/10.1007/s10734-013-9618-8

Allen, N. J., Meyer, J. P., 1990. The measurement and antecedents of affective, continuance and normative commitment to the organization. Journal of Occupational Psychology 63, 1-18.

URL: https://doi.org/10.1111/j.2044-8325.1990.tb00506.x

Ashikali, T., Groeneveld, S., 2015. Diversity management in public organizations and its effect on employees' affective commitment: The role of transformational leadership and the inclusiveness of the organizational culture. Review of Public Personnel Administration 35, 146-168. URL: https : //doi .org/10.1177/0734371X13511088

Avolio, B. J., Zhu, W., Koh, W., Bhatia, P., 2004. Transformational leadership and organizational commitment: mediating role of psychological empowerment and moderating role of structural distance. Journal of Organizational Behavior J. Organiz. Behav 25, 951-968. URL: https : //doi.org/10.1002/job. 283

Bass, B. M., Avolio, B. J., Jung, D. I., Berson, Y., 2003. Predicting unit performance by assessing transformational and transactional leadership. Journal of Applied Psychology 88, 207-218. URL: https://doi.org/10.1037/0021-9010.88.2.207 
Bentler, P., 1990. Quantitative methods in psychology: Comparative fit indexes in structural models. Psychological Bulletin 107, 238-246.

URL: https://search.proquest.com/docview/614296051/ full textPDF/812BB1058BD74A66PQ/8? accountid=14744

Brislin, R. W., 1970. Back-translation for cross-cultural research. Journal of Cross-Cultural Psychology 1, 185-216.

URL: https://doi.org/10.1177/135910457000100301

Cropanzano, R., Prehar, C. A., Chen, P. Y., 2002. Using social exchange theory to distinguish procedural from interactional justice. Group and Organization Management 27, 324-351.

URL: https://doi.org/10.1177/1059601102027003002

Etikan, I., Musa, S. A., Alkassim, R. S., 2016. Comparison of convenience sampling and purposive sampling. American Journal of Theoretical and Applied Statistics 5, 1-5.

URL: https://doi.org/10.11648/j .ajtas.20160501.11

Fabrigar, L. R., Wegener, D. T., Maccallum, R. C., Strahan, E. J., 1999. Evaluating the use of exploratory factor analysis in psychological research. Psychological Methods 4, 272-299.

Gulluce, A. Ç., Kaygin, E., Kafadar, S. B., Atay, M., 2016. The Relationship between transformational leadership and organizational commitment: A study on the bank employees. Journal of Service Science and Management, 09 , 263-275.

URL: https://doi.org/10.4236/jssm.2016.93033

Gumusluoglu, L., Ilsev, A., 2008. Transformational leadership, creativity, and organizational innovation. Journal of Business Research 62, 461-473. URL: https://doi .org/10.1016/j.jbusres . 2007.07.032

Hu, L.-T., Bentler, P. M., 1999. Cutoff criteria for fit indexes in covariance structure analysis: Conventional criteria versus new alternatives. Structural Equation Modeling: Multidisciplinary Journal 6, 1-55. URL: https://doi.org/10.1080/10705519909540118

Islam, T., Khan, S. u. R., Ahmad, U. N. U. B., Ahmed, I., 2013. Organizational learning culture and leader-member exchange quality: The way to enhance organizational commitment and reduce turnover intentions. Learning Organization 20, 322-337.

URL: https://doi.org/10.1108/TLO-12-2012-0079

Khatibi, A., Asadi, H., Hamidi, M., 2009. The relationship between job stress and organizational commitment in national olympic and paralympic academy. World Journal of Sport Sciences 2, 272-278.

Khunsoonthornkit, A., Panjakajornsak, V., 2018. Structural equation model to assess the impact of learning organization and commitment on the performance of research organizations. Kasetsart Journal of Social Sciences 39, 457-462.

URL: https://doi.org/10.1016/j.kjss.2018.07.003

Kim, H., 2014. Transformational leadership, organizational clan culture, organizational affective commitment, and organizational citizenship behavior: A case of South Korea's public sector. Public Organization Review 14, 397417.

URL: https://doi.org/10.1007/s11115-013-0225-z

Marsick, V. J., Watkins, K. E., 2003. Demonstrating the value of an organization's learning culture: The dimensions of the learning organization questionnaire. Advances in Developing Human Resources 5, 132-151. URL: https://doi .org/10.1177/1523422303251341

Memon, M. A., Cheah, J.-H., Ramayah, T., Ting, H., Chuah, F., Cham, T. H., 2019. Moderation analysis: Issues and guidelines. Journal of Applied Struc- tural Equation Modeling 3, 1 .

URL: https://doi.org/10.47263/jasem.3(1)01

Mercurio, Z. A., 2015. Affective commitment as a core essence of organizational commitment: An integrative literature review. Human Resource Development Review 14 (4), 389-414.

URL: https://doi.org/10.1177/1534484315603612

Meyer, A. D., 1982. Adapting to environmental jolt. Administrative Science Quarterly 27, 515-537.

Meyer, J. P., Allen, N. J., Smith, C. A., 1993. Commitment to organizations and occupations: Extension and test of a three-component conceptualization. Journal of Applied Psychology 78, 538-551.

URL: https://doi.org/10.1037/0021-9010.78.4.538

Meyer, J. P., Stanley, D. J., Herscovitch, L., Topolnytsky, L., 2002. Affective, continuance, and normative commitment to the organization: A metaanalysis of antecedents, correlates, and consequences. Journal of Vocational Behavior 61, 20-52.

URL: https://doi.org/10.1006/jvbe. 2001.1842

Podsakoff, P. M., MacKenzie, S. B., Lee, J. Y., Podsakoff, N. P., 2003. Common method biases in behavioral research: A critical review of the literature and recommended remedies. Journal of Applied Psychology 88, 879-903.

URL: https://doi.org/10.1037/0021-9010.88.5.879

Porter, J. A., 2015. The relationship between transformational leadership and organizational commitment in nonprofit long term care organizations: The direct care worker perspective. Creighton Journal of Interdisciplinary Leadership 1, 68-85.

URL: https://doi.org/10.17062/cjil.v1i2.13

Pradhan, S., Pradhan, R. K., 2015. An empirical investigation of relationship among transformational leadership, affective organizational commitment and contextual performance. Vision: The Journal of Business Perspective 19, 227-235.

URL: https://doi.org/10.1177/0972262915597089

Ramachandran, S., Krishnan, V. R., 2009. Effect of transformational leadership on followers' affective and normative commitment: Culture as moderator. Great Lakes Herald 3, 23-38.

Sekliuckiene, J., Vaitkiene, R., Vainauskiene, V., 2018. Organisational learning in startup development and international growth. Entrepreneurial Business and Economics Review 6 (4), 125-144.

URL: https://doi.org/10.15678/EBER.2018.060407

Sharma, P., Sinha, V., 2015. The influence of occupational rank on organizational commitment of faculty members. Management - Journal of Contemporary Management Issues 20 (2), 71-91.

Triana, M. D. C., Richard, O. C., 2017. \& Y $\{$ "u $\}$ cel, \{\} , journal = $\{$ I $\}$. Status incongruence and supervisor gender as moderators of the transformational leadership to subordinate affective organizational commitment relationship 70, 429-467.

URL: https://doi.org/10.1111/peps. 12154

Yang, B., Watkins, K. E., Marsick, V. J., 2004. The construct of the learning organization: Dimensions, measurement, and validation. Human Resource Development Quarterly 15, 31-55.

URL: http://assets.csom. umn. edu/assets/21929.

pdf $\{\%\}$ Ahttp://eds.a.ebscohost.com. lopes .

idm.oclc.org/eds/pdfviewer/pdfviewer?sid=

0c2eab39-43d5-4646-b07a-

e8c5a2a7d324 $\{\%\} 40$ sessionmgr $4008\{\&\}$ vid $=5\{\&\} \mathrm{hid}=4205$ 